\title{
TEMBUNG LAN GAMBARE \\ KAMUS VISUAL RAGAM DIKSI BAHASA JAWA TINGKAT NGOKO
}

\author{
Edi Jatmiko \\ Program Studi Desain Komunikasi Visual \\ Fakultas Seni Rupa ISI Yogyakarta \\ rubahsiang@gmail.com
}

\begin{abstract}
Java language as a mother language, has a complicated character, and terraced difficult even for Javanese society itself. The level of complexity in the Java language system is one of the factors that led to the Java language is considered less desirable and not match the needs of the times by the Java community itself. This difficulty is caused by one of the Java language has a complete vocabulary, diction diverse, in one term in Indonesian, can be assorted due to the mention of the Java language that caused chronology. Javanese society has the ability to mark the various forms of work in different terms though just because of small differences. Diction of the diversity of conditions in the Java language ngoko level, ie the level of the language most widely used Java community need for adequate instructional media. One of the gaps that can be addressed in greater depth is how to bring learning the Java language into a form that is easily understood visual communication method is to create a visual dictionary of the Java language.
\end{abstract}

Keywords: Java language, Illustration, Visual dictionary, Diction diverse

Relevance to Visual Communication Design Practice: This paper can be used as a visual dictionary based on verbal language.

\section{PENDAHULUAN}

Suatu ketika dalam kegiatan pembuatan film pendek, sutradara yang berasal dari etnis non Jawa yang menggunakan bahasa nasional memberikan instruksi kepada talent yang bersuku Jawa. Instruksi adegannya adalah pemeran membawa sebuah benda dan memindahkannya ketempat lain. Lalu pemeran bertanya dengan dialek Jawanya, bagaimanakah ia harus membawa benda yang dimaksudkan; "disunggi, dijinjing, diangkut, dipikul, digeret, diseret, disurung, dikendit, dibopong, dipanggul, digendong?" dari dialog yang terjadi inilah timbul sebuah pemikiran, bahwa nyatanya orang Jawa terwarisi bahasa yang begitu detailnya dalam menandai setiap kata kerja. Tersadar bahwa untuk menyebut satu istilah membawa sebuah barang saja, bahasa Jawa memiliki banyak sebutan, bukan sinonim atau padanan kata, melainkan istilah yang berbeda. Perbedaan isitilah ini digunakan untuk menandai posisi dan kronologi yang berbeda meskipun tujuannya sama yakni membawa.

Membahas mengenai bahasa ibu, National Geographic Indonesia edisi Juli 2012, dalam artikel berjudul Suara-Suara Yang Sirna, di ada satu pembahasan yang mengejutkan, ada sebuah artikel yang dibuka dengan paragraf dengan huruf-huruf yang di tebalkan;

Satu bahasa punah setiap 14 hari. Sebelum abad berganti, hampir setengah dari sekitar 7.000 bahasa yang dipakai di bumi mungkin akan punah, karena masyarakat mengganti bahasa ibunya dengan bahasa 
Inggris, Mandarin, atau Spanyol. Apa yang hilang ketika suatu bahasa lenyap?

Meski pembahasan bahasa yang dinyatakan punah maupun dalam posisi terancam adalah bahasa-bahasa ibu yang terdapat di negara-negara eropa, namun kekhawatiran itupun kian terasa saat menginggat bahasa ibu di Nusantara ini begitu banyak jumlahnya. Sebelum National Geographic membahas tentang kepunahan bahasa, Kompas edisi 27 Mei 2009 memaparkan kesimpulan yang dikeluarkan oleh Pusat Bahasa. Disebutkan dalam artikel tersebut bahwa kepunahan bahasa daerah di Indonesia dipetakan sebagai berikut :

Di Kalimantan 50 bahasa daerah terancam punah dan satu sudah punah. Dari 13 bahasa di Sumatra, dua terancam punah dan satu sudah punah.Sulawesi yang memiliki 110 bahasa, 36 terancam punah dan satu sudah punah. Dari 80 bahasa daerah di Maluku, 22 terancam punah dan 11 sudah punah. Di daerah Timor, Flores, Bima, dan Sumba dari 50 bahasa yang ada sebanyak delapan terancam punah. Di daerah Papua dan Halmahera dari 271 bahasa sebanyak 56 bahasa terancam punah. Di Jawa tidak ada bahasa daerah terancam punah.

Dari artikel tersebut yang menarik untuk dicermati adalah pada kalimat terakhir yakni di Jawa tidak ada bahasa daerah yang terancam punah. Sebagai orang Jawa yang lahir dan menetap serta berkumpul dan bertetangga dengan sesama orang Jawa, pernyataan diatas tak lantas menentramkan hati orang Jawa. Seperti yang kita tahu bahasa Jawa memiliki tingkatan-tingkatan bahasa yang berlaku. Terdapat tiga bentuk utama variasi, yaitu ngoko (kasar), madya (biasa), dan krama (halus). Di antara masing-masing bentuk ini terdapat bentuk "penghormatan" (ngajengake, honorific) dan "perendahan" (ngasorake, humilific). Seseorang dapat berubah-ubah registernya/ undhakundhak/tingkatan bahasa tergantung karakter dari lawan bicara yang bersangkutan. Karakter bisa ditentukan umur, jenis kelamin/gender, kelas sosial ekonomi, kelas sosial kemasyarakatan, pendidikan, pekerjaan, dan domisili penutur, atau hal-hal lain. Bahasa Jawa menerapkan falsafah "tumata" dengan menempatkan lawan bicara semestinya hingga dikenalah bentuk-bentuk ngoko lugu, ngoko andhap, madhya, madhyantara, krama dan krama inggil.

Banyak orang Jawa yang mengeluhkan betapa sulitnya belajar bahasa Jawa ditingkat madya dan krama. Alhasil, tingkat ngoko-lah yang kerap dipakai untuk berbahasa seharihari, meskipun terhadap orang tua yang seharusnya menggunakan tingkatan krama. Diera dimana kepraktisan menjadi suatu kebutuhan penting, keberadaan undhakundhak (tingkatan) bahasa Jawa sedikit demi sedikit ditinggalkan. Tak hanya itu, bahkan di tingkat ngoko, banyak kosakata yang dianggap lewah (tidak perlu). Barangkali hal ini tidak perlu dikuatirkan untuk generasi yang lahir sebelum generasi muda saat ini, namun untuk generasi muda saat ini dan yang mendatang, perlu adanya upaya pemertahanan bahasa Jawa sebagai bahasa $\mathrm{ibu/daerah.}$

Banyaknya faktor eksternal yang mengakibatkan bahasa Jawa mulai ditinggalkan perlahan-lahan oleh para pewarisnya, namun pengaruh lebih besar adalah pada faktor internalnya yakni bahasa Jawa adalah bahasa yang sulit dan rumit. Salah satu celah yang bisa ditanggapi secara 
lebih mendalam adalah bagaimana menghadirkan pembelajaran bahasa Jawa kedalam bentuk yang mudah dipahami dan menyenangkan. Salah satu yang bisa dilakukan adalah menciptakan kamus visual bahasa Jawa. Selain menjadi media pembelajaran, kamus dapat pula dijadikan sebagai pemertahanan bahasa secara dokumentasi dan kearsipan. Kamus visual memungkinkan orang lebih mudah dalam memahami istilah dan kosakata bahasa Jawa, tentunya kamus visual terbatas pada kata kerja dan kata benda.

\section{HASIL DAN PEMBAHASAN}

\section{a. Bahasa Jawa dan Permasalahanya}

Dalam kesehariannya masyarakat Jawa minimal harus menguasai dua bahasa, yakni bahasa Indonesia sebagai bahasa Nasional dan Bahasa Jawa sebagai bahasa keseharian. Beberapa anggota kelompok masyarakat Jawa tertentu memiliki beban tambahan penguasaan bahasa, yakni selain bahasa Indonesia dan bahasa Jawa, harus pula menguasai bahasa asing karena tuntutan pekerjaan, misal bahasa Inggris, Perancis, bahasa-bahasa dinegara Asia. Situasi seperti ini oleh para ahli bahasa disebut sebagai multilangualisme. Bahkan tak sedikit pula kemampuan multilangualisme ketiga bahasa tadi masih ditambah dengan bahasa Arab karena adanya tuntutan pemahaman agama Islam yang dominan di anut masyarakat Jawa.

Chaer (2003:65), menyatakan bahwa bilingualisme dan multilingualisme dalam masyarakat Indonesia cenderung mengakibatkan timbulnya gejala alih kode (code-switching), campur kode (code-mixing), dan interferensi (interference). Alih kode adalah penggunaan dua bahasa atau variasi bahasa secara berganti-ganti di dalam wacana yang sama. Pembicara bilingual itu beralih dari perangkat sistem bahasa yang satu ke perangkat sistem bahasa yang lain. Campur kode berbeda dari alih kode; campur kode adalah pengambilan elemen secara tetap dari bahasa lain ke dalam bahasa yang sedang dipakai karena tidak ada elemen yang tepat dalam bahasa yang dipakainya itu. interferensi (pengacauan); inteferensi adalah perubahan bentuk bahasa sebagai akibat dari penerapan dua buah sistem bahasa yang berbeda secara serempak. Kondisi Bilingualisme dan multilangualisme dalam masyarakat Jawa menyebabkan sedikit banyak kerusakan pada bahasa Jawa itu sendiri. Kerusakan dapat berupa tertukarnya kosakata, penggunaan serapan yang tidak perlu, hal ini menyebabkan banyak kosakata yang hilang.

Selain kondisi bilingualisme dan multilangualisme yang harus diterapkan masyarakat Jawa, secara internal bahasa Jawa memiliki ciri yang membedakanya dengan bahasa-bahasa lain di dunia. Karakter bahasa Jawa berciri banyaknya keragaman diksi, perbedaan-perbedaan logat tiap daerah meskipun bersebelahan, detail-detail kosakata dan istilah untuk menjelaskan tiap-tiap hal yang sama namun berbeda kronologi, ada taingkatan-tingkatan yang harus dipahami dalam membedakan partisipan yang diajak berkomunikasi. Hal ini menjadikan Bahasa Jawa adalah bahasa yang sulit dan rumit untuk dipelajari, baik oleh penutur dari suku Jawa maupun orang-orang diluar Jawa yang ingin mempelajari bahasa Jawa. Tetapi disisi lain, justru inilah kelebihan bahasa Jawa. 
Dengan keragaman kata dan tingkatan, bahasa ini mengajarkan pada kita nilai nilai keluhuran dan kesopanan yang tidak diajarkan oleh bahasa lain di dunia, termasuk bahasa nasional Bahasa Indonesia. Bahasabahasa daerah terkadang dianggap sebagai bahasa yang kurang fleksibel dan kurang mengikuti perkembangan jaman. Generasi yang terlahir secara biologis dari keturunan etnis Jawa kini kurang begitu mengerti dan antusias menggunakan bahasa tersebut, karena ada yang merasa bahwa bahasa Jawa terlalu rumit bagi mereka, banyak kosakata dari bahasa Jawa yang tidak dimengerti, ditambah dengan penggunaan tingkat tutur bahasa Jawa dan sebagainya. Hal tersebut merupakan indikasi bahwa mereka sudah tidak berminat lagi untuk mempelajari bahasa Jawa, atau hal itu juga dipengaruhi oleh perkembangan keadaan yang menghendaki segala sesuatu yang serba praktis dan instan.

Sikap negatif juga akan lebih terasa akibatnya apabila seseorang atau sekelompok orang tidak mempunyai kesadaran akan adanya norma bahasa. Sikap tersebut nampak dalam tindak tuturnya. Mereka tidak merasa perlu untuk menggunakan bahasa secara cermat dan tertib, mengikuti kaidah yang berlaku. Atau karena khawatir salah dan kurang tepat dalam pemilihan kata saat berbicara dengan orang yang lebih tua maka sebagian besar penutur bahasa Jawa menggunakan bahasa ngoko atau Bahasa Indonesia untuk menghindari kesalahan tersebut. Umumnya orang Jawa akan lebih malu jika salah dalam menggunakan bahasa Jawa tingkatan kromo inggil misalnya daripada menggunakan bahasa ngoko seluruhnya meskipun terhadap orang yang lebih tua. Untuk sebagian yang lain memilih penggunaan Bahasa Indonesia sebagai alternatif yang aman.

\section{b. Kamus visual}

Kamus merupakan hasil kerja dari leksikografi, sebuah cabang linguistik yang khusus mempelajari kamus. Secara etimologi kamus berasal dari kata dalam bahasa Arab, yakni qamus (bentuk jamaknya qawamus). Padanan kata dalam bahasa Inggris adalah dictionary dan pada masa penjajahan di Indonesia menggunakan bahasa Belanda yakni woordenboek yang dalam bahasa Indonesia dipadankan dengan perbendaharaan kata atau kosakata (Abdul Chaer, 2007). Didalam bahasa Jawa terdapat penyebutan yang detail untuk sebuah pengertian yang sama, namun berbeda istilah karena kronologi, posisi, atau bentuk yang berbeda. Jadi bukan berbentuk synonim karena sesungguhnya bukan padanan kata melainkan pengertian yang sama namun berbeda isitlah berdasarkan atribut yang menempel pada kata tersebut.

Kamus visual telah diakui keefektifannya dalam dunia pembelajaran. Banyaknya makna-arti kata yang tak mampu menjelaskan suatu pemahaman tertentu dapat diterangkan dengan mudah oleh gambar. Gambar/ ilustrasi mampu mengekspresikan atau memperlihatkan objek/dunia yang kita lihat. Ekspresi terjadi karena adanya persepsi yang kita tangkap dengan visual yang kita lihat ditambah dengan intusi dan pengalaman. Dengan gambar pula kamus dapat mendeskripsikan objek dan lingkungannya. Obyek dan lingkungan terpampang tak selalu menyertakan informasi yang bisa langsung ditangkap oleh indera. Gambar berperan penting mendiskripsikan 
sebuah benda dan keberadaanya pada sebuah lingkungan. Gambar/ ilustrasi dapat memperjelas atau mempertajam kepekaan akan sebuah bentuk. Indera kita terbatas dalam menangkap sebuah obyek karena keterbatasan ruang, namun dengan gambar mata kita dibantu dengan visual-visual yang tak mampu ditangkap oleh retina.

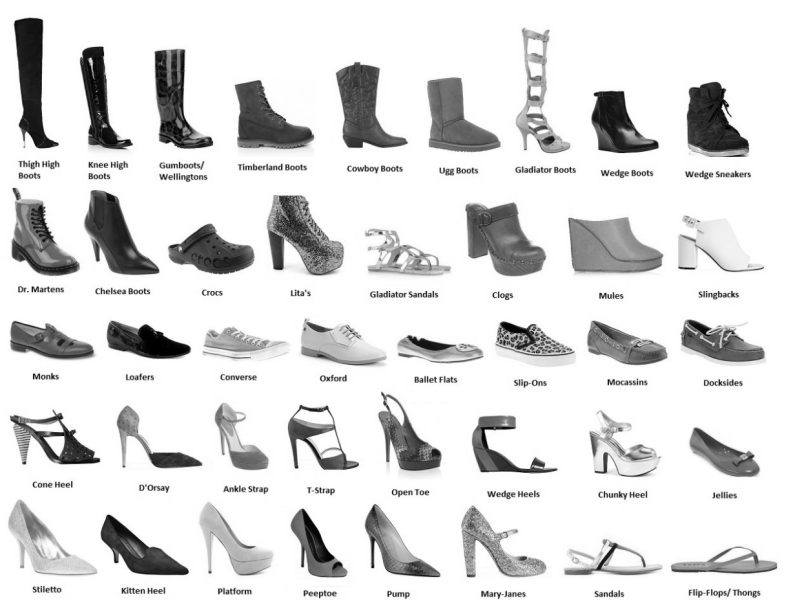

Gambar 1 Berbagai macam jenis alas kaki Sumber : Visual Shoe Dictionary

Sebagai contoh gambar diatas, nyatanya banyak sekali jenis alas kaki yang ada didunia ini. Alas kaki tersebut memiliki atribut yang beragam, mulai dari warna, bahan, bentuk, fungisonal maupun desain. Atribut-atribut tersebut akan sulit kita pahami ketika tidak ada bantuan visual.

\section{c. Keragaman Diksi Bahasa Jawa}

Dari sudut pandang Setting tempat, klasifikasi bahasa Jawa berdasarkan dialek geografi pulau Jawa terbagi dalam enam dialek atau aksen atau logat yang berbeda yakni dialek Jawa-Sunda, Banyumasan, Kedu, SoloYogyakarta, Semarangan dan dialek Jawa Timuran. Beragamnya dialek ini menyebabkan beragam pula kosakata dalam bahasa Jawa. Namun perancangan ini dikhususkan pada dialek Solo-Yogyakarta. Pengumpulan frasa dibatasi pada tingkat tutur ngoko, dan dikhusukan pada kata kerja atau dalam bahasa Jawa disebut 'tembung kriya'. Hal ini dimaksudkan karena bahasa Jawa tingkat tutur ngoko memiliki hiponim paling banyak. Data entri kosakata diambil dari kamus bahasa Jawa yang umum digunakan. Namun mengingat frasa yang akan di visualkan tidak banyak dibahas di dalam kamus yang telah ada, jikapun ada hanya terjemahan per kata bukan penjelasan terperinci, maka data entri lebih banyak diambil dari wawancara kepada pihak-pihak yang menguasai bahasa Jawa dengan baik, maupun dengan generasi-generasi tua yang saat ini masih paham dengan kosakata bahasa Jawa.

Hiponim-hiponim tersebut perlu dijelaskan secara visual karena perbedaan posisi dan kronologi pada tembung kriya bahasa Jawa terkadang hanya sangat tipis, namun sudah diberi istilah baru. Dalam semantik, hiponim adalah suatu kata atau frasa yang maknanya tercakup dalam kata atau frasa lain yang lebih umum, yang disebut hiperonim atau hipernim. Kata hiponimi berasal dari bahasa Yunani kuno, yaitu onoma berarti "nama" dan hypo berarti "di bawah". Jadi, secara harfiah berarti "nama yang termasuk di bawah nama lain". Sesuai dengan yang diungkapkan Keraf (2005:38) Hiponimi adalah semacam relasi antar kata yang berwujud atas bawah, atau dalam suatu makna terkandung sejumlah komponen yang lain. Karena ada kelas atas yang mencakup sejumlah komponen yang lebih kecil dan ada kelas bawah yang merupakan komponen komponen yang tercakup dalam kelas atas, 
maka kata yang berkedudukan di kelas atas ini disebut superordinat dan kata yang berada di kelas bawah disebut hiponim.

Berikut contoh beragamnya hiponim dalam bahasa Jawa ngoko dari hipernim tiba / terjatuh:

\section{hiponim 1: Kesandung}

Terjatuh karena kaki bagian bawah atau ujung kaki terhambat oleh benda timbul pada permukaan rata atau mendekati datar. Benda ini dapat berupa benda keras atau benda yang melekat permukaan permukaan sekitarnya. Pada umumnya posisi tubuh terjatuh kearah depan. Kesandung berasal dari kata dasar sandung, ketika memiliki awalan ke- maka mengartikan bahwa kejadian yang tidak disengaja.

\section{hiponim 2 : Kesrimpet}

Tubuh yang terjatuh diakibatkan kaki bagian bawah tersangkut oleh benda umumnya benda lentur namun bersiat lebar atau panjang, misal tali atau kain. Kesrimpet berasal dari kata dasar srimpet, ketika memiliki awalan ke- maka mengartikan bahwa kejadian yang tidak disengaja.

\section{hiponim 3 : Kejiret}

Seperti halnya kesrimpet, kejiret adalah terjatuh akibat oleh benda lentur umumnya oleh tali. Namun yang membedakan dengan kesrimpet adalah tali yang menyebabkan terjatuh membentuk ikatan pada kaki.

\section{hiponim 4 : Kejeglong/ kejeblos}

Terjatuh akibat terperosok lubang pada permukaan yang seolah-olah tidak berlubang karena tertutup sebuah benda lain. Kejeglong pada umumnya pelaku tidak menyadari bahwa ada bagian permukaan yang lebih rendah dari permukaan lainnya, termasuk pula pada tangga.

hiponim 5 : Kepleset

Terjatuh akibat menginjak benda atau permukaan yang licin. Umumnya posisi jatuhnya bisa kedepan maupun kebelakang.

\section{hiponim 6 : Kejlungup}

Terjatuh dengan posisi tertelungkup kedepan, umumnya diakibatkan berlari terlalu kencang sehingga tubuh tidak terkendali.

\section{hiponim $7:$ Kedringes}

Terjatuh yang diakibatkan posisi tepak kaki yang salah, atau dikarenakan alas kaki terlalu tinggi, umumnya terjatuh ke tubuh bagian samping.

\section{hiponim $8:$ Kejegal}

Terjatuh yang diakibatkan karena kaki dihalangi oleh kaki orang lain secara sengaja. Posisi yang menjegal bisa dari samping maupun belakang.

\section{hiponim 9 : Kejebur}

Terjatuh ke area yang berair, umumnya terjatuh kedepan karena dorongan dari belakang

\section{hiponim 10 : Kecemplung}

Terjatuh kedalam area atau lubang yang berair, bukan karena dorongan dari belakang namun umumnya dari atas ke bawah.

\section{hiponim 11 : Keblekok}

Tertajuh/atau tidak bisa beranjak karena bagian kaki yang terjebak dalam lumpur yang liat. 
hiponim 12 : Ambruk

Tersungkur karena disebabkan oleh dorongan benda lain atau sebab dari dirinya sendiri misalnya pingsang, ambruk terjadi umumnya karena kaki tidak kuat menahan beban tubuh, posisi tubuh bisa terjatuh ke segala arah.

\section{hiponim 13 : Nggeblak}

Terjatuh kebelakang, biasanya terjadi tiba-tiba karena shock atau terkejut.

\section{hiponim 14 : Njengkang}

Terjatuh karena kaki terhalang sesuatu pada saat pelaku berjalan mundur.

\section{hiponim 15 : Ndoprok}

Teduduk dari posisi berdiri, pada saat ndoprok beban tubuh tertumpu pada kedua kaki yang ditekuk. Ndoprok terjadi karena proses biologis tertentu misal lemas karena kurang makan atau sifatnya mental misal karena terkejut atau terlalu sedih.

Dari sample hipernim-hiponim bahasa ngoko diatas, maka jika diterjemahkan ke dalam bahasa gambar menjadi:

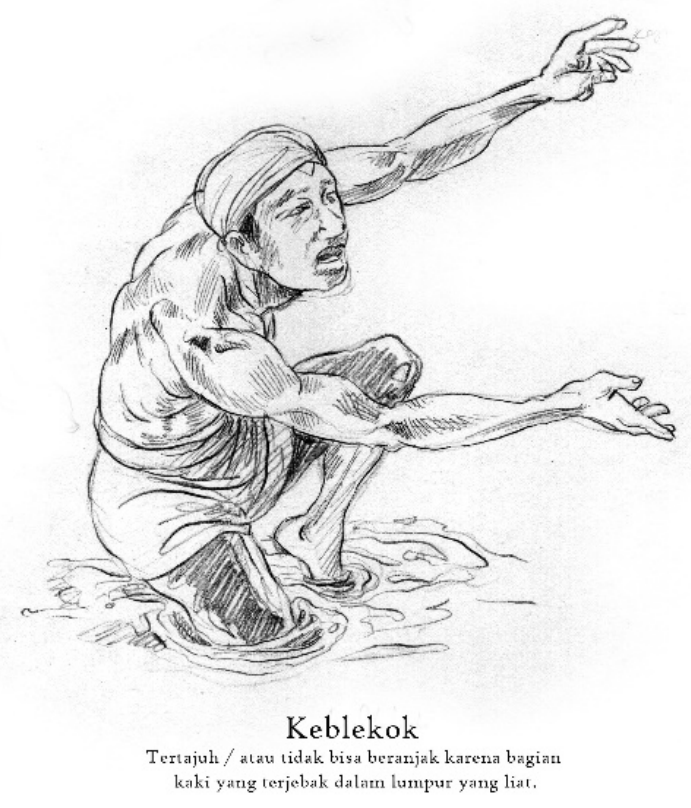

Gambar 2 Visualisasi hipernim jatuh kedalam hiponim-hiponimnya bag. 1 Sumber: penulis 


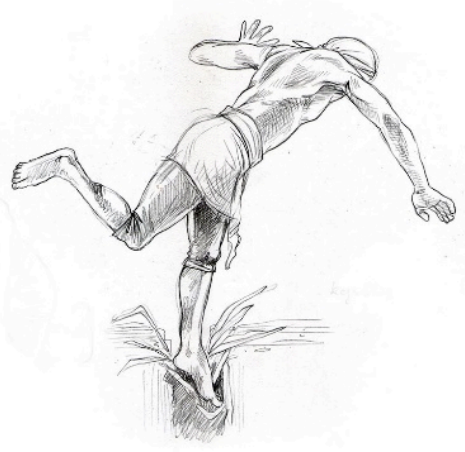

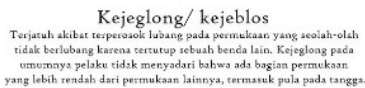
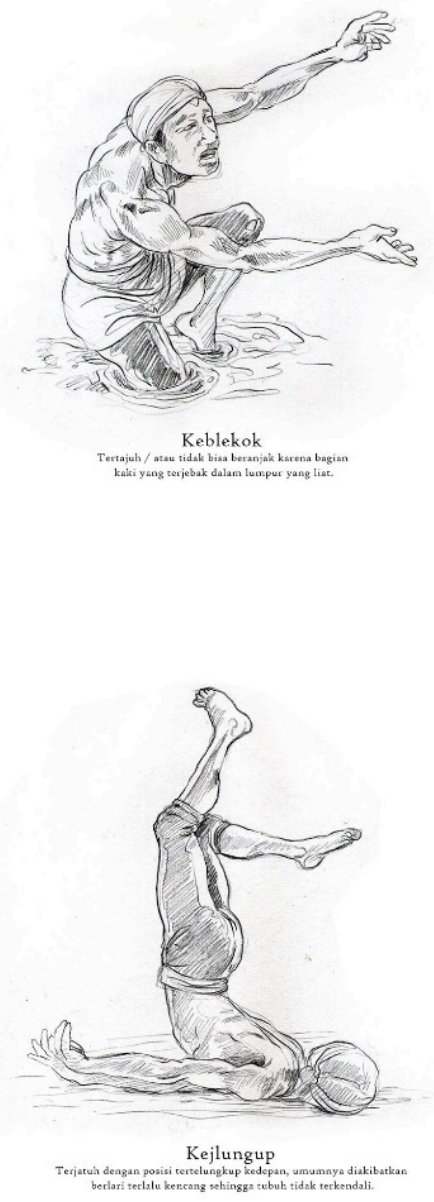
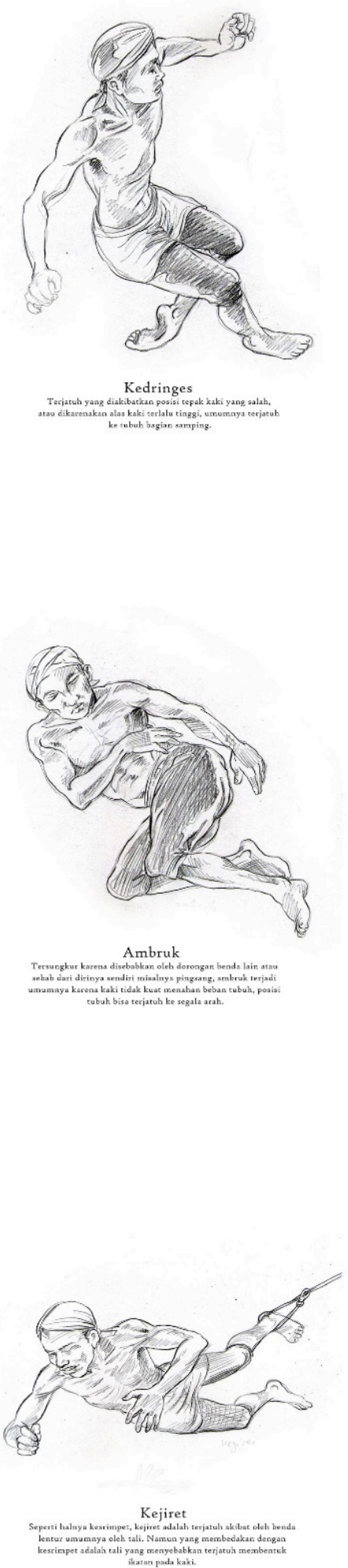

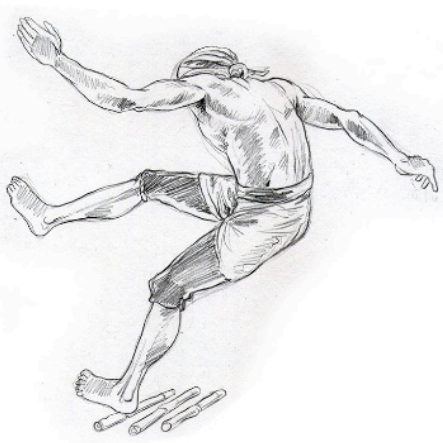

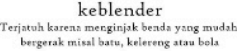
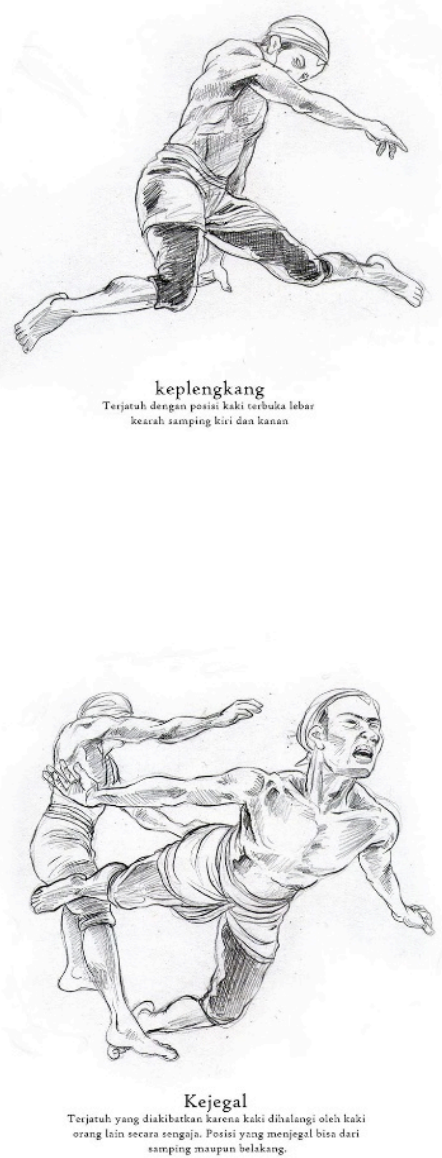

Gambar 3 Visualisasi hipernim jatuh kedalam hiponim-hiponimnya bag. 2 Sumber : penulis 


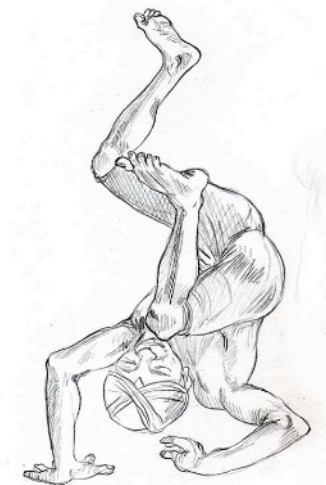

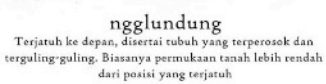

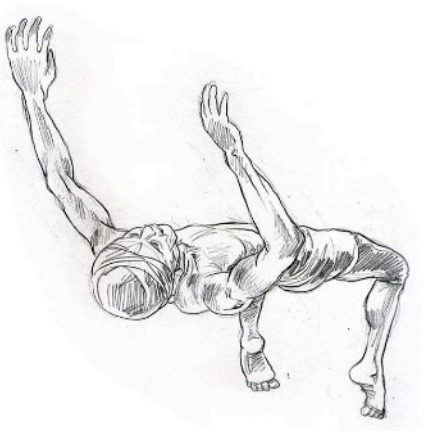

kontal
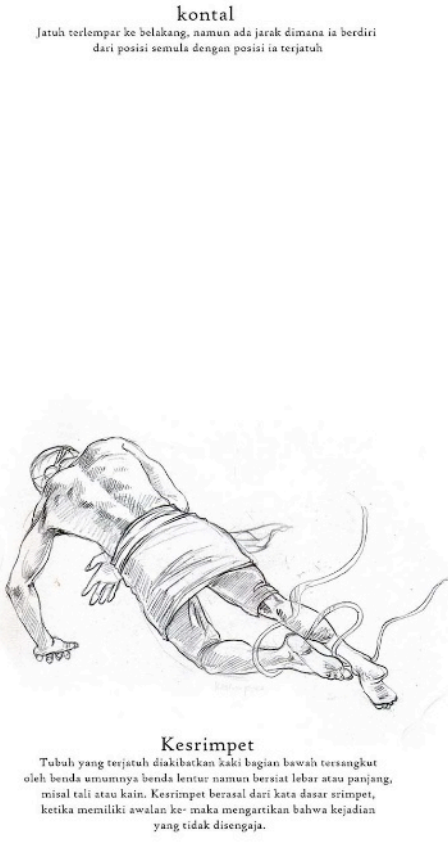
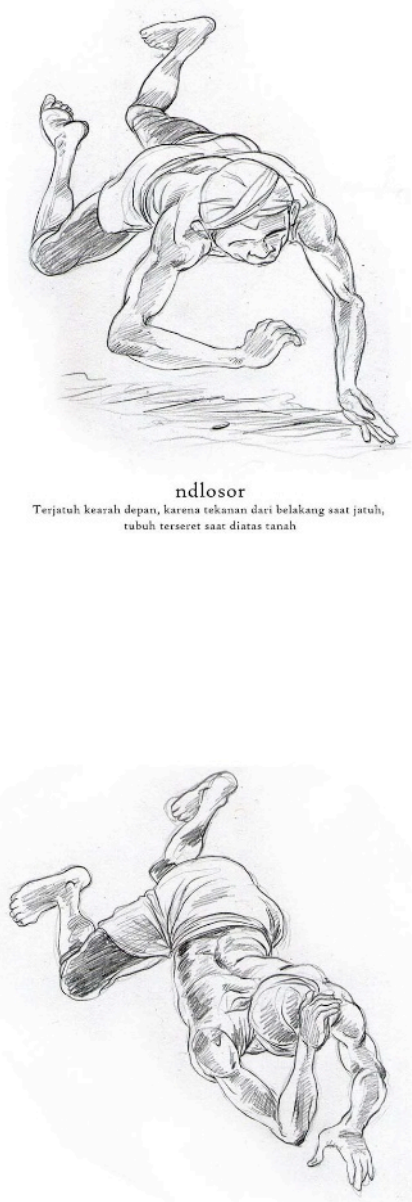

ndlosor
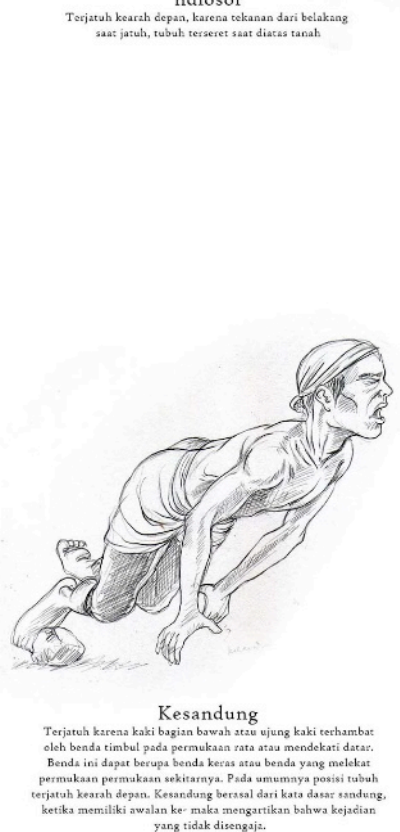
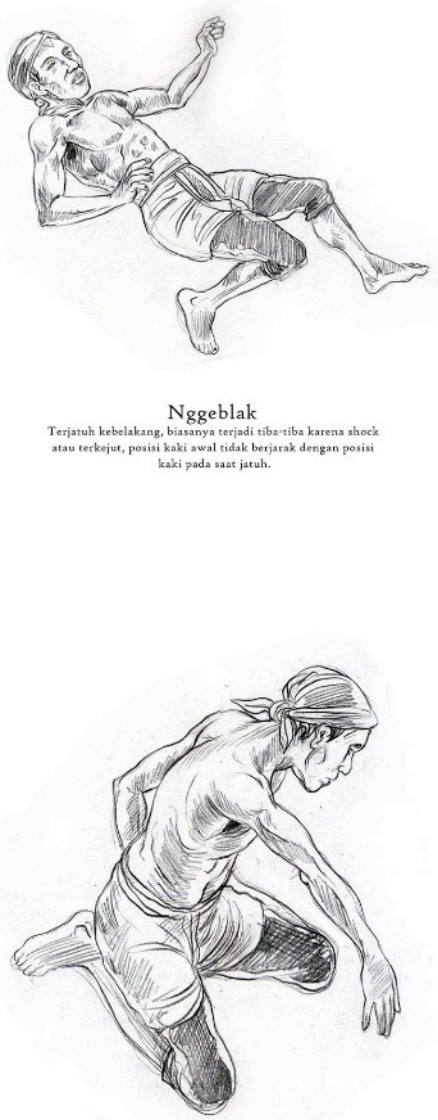

Ndoprok
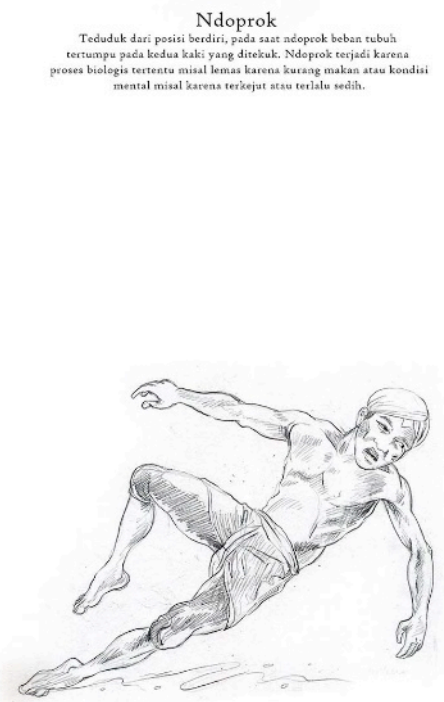

Kepleset

Gambar 4 Visualisasi hipernim jatuh kedalam hiponim-hiponimnya bag. 3 Sumber : penulis 


\section{KESIMPULAN}

Ditingkat pendidikan formal, didaerah berpenduduk mayoritas suku Jawa, Bahasa Jawa diposisikan sebagai mata pelajaran yang dianggap tidak penting. Dari pendidikan dasar hingga mengengah pelajaran bahasa lebih menitik beratkan pada bahasa Indonesia dan bahasa asing dari pada Bahasa Jawa. Inilah yang menjadi titik lemah dari proses pembudayaan bahasa Jawa, ditambah lagi status pelajaran bahasa Jawa yang hanya menjadi mata pelajaran muatan lokal. Pelajaran muatan lokal tidak memiliki bergaining dibanding mata pelajaran lain seperti matematika atau sains. Salah satu penyebabnya adalah faktor media pembelajaran yang terbatas dan tidak menarik menjadi permasalahan terhambatnya pelajaran bahasa Jawa.

Dengan menghadirkan pembelajaran bahasa Jawa kedalam bentuk yang mudah dipahami dan menyenangkan dimungkinkan adanya ketertarikan masyarakat terutama para pelajar mendalami bahasa Jawa. Salah satu usulan pemecahan masalah berbasis DKV adalah dengan menciptakan kamus visual bahasa Jawa. Dengan kelebihan verbalvisual, kamus visual lebih memudahkan audiens dalam memahami istilah dan kosakata bahasa Jawa.

\section{SARAN}

Perlu ada perhatian bersama terhadap upaya pemertahanan bahasa Jawa sebagai bahasa ibu, yang kian hari mendapat tantangan yang semakin serius dari berbagai farktor. Salah satu upaya yang dilakukan dengan pemecahan visual membutuhkan kerja sama dari disiplin ilmu yang terkait. Dalam hal ini perlu kerjasama dengan para ahli bidang linguistik yang memberi perhatian khusus pada bahasa Jawa. Kerjasama ini diupayakan untuk saling menutupi kekurangan dari masing pihak, yakni pihak desainer sebagai penerjemah bahasa kedalam bentuk visual dan ahli bahasa sebagai pihak yang memiliki kapasitas keilmuan dalam bidang bahasa Jawa.

\section{DAFTAR PUSTAKA}

[1] Chaer, Abdul. 2007. Leksikologi dan leksikografi Indonesia. Jakarta: Rineka Cipta

[2] Sindunata, kitab Si Taloe, Gambar Watjan Botjah 1909-1961, bentara Budaya Yogyakarta 2008.

[3] Wedhawati, Tata Bahasa Jawa Mutakhir Edisi Revisi, Penerbit Kanisius Yogyakarta, 2006.

Majalah National Geographic Indonesia edisi Juli 2012

Kompas Edisi 27 Mei 2009 